\title{
บusisersaly
}

\section{An assessment of the performance of municipal constructed wetlands in Ireland.}

Hickey, A., Arnscheidt, J., Joyce, E., o'Toole, J., Galvin, G., o' Callaghan, M., Conroy, K., Killian, D., Shryane, T., Hughes, F., Walsh, K., \& Kavanagh, E. (2018). An assessment of the performance of municipal constructed wetlands in Ireland. Journal of Environmental Management, 210, 263-272.

https://doi.org/10.1016/j.jenvman.2017.12.079

Link to publication record in Ulster University Research Portal

Published in:

Journal of Environmental Management

Publication Status:

Published (in print/issue): 15/03/2018

DOI:

10.1016/j.jenvman.2017.12.079

\section{Document Version}

Author Accepted version

\section{General rights}

Copyright for the publications made accessible via Ulster University's Research Portal is retained by the author(s) and / or other copyright owners and it is a condition of accessing these publications that users recognise and abide by the legal requirements associated with these rights.

\section{Take down policy}

The Research Portal is Ulster University's institutional repository that provides access to Ulster's research outputs. Every effort has been made to ensure that content in the Research Portal does not infringe any person's rights, or applicable UK laws. If you discover content in the Research Portal that you believe breaches copyright or violates any law, please contact pure-support@ulster.ac.uk. 


\title{
AUTHOR MANUSCRIPT
}

An assessment of the performance of municipal constructed wetlands in Ireland

Anthony Hickey ${ }^{\mathrm{a}}$, Joerg Arnscheidt ${ }^{\mathrm{b}}$, Eadaoin Joyce ${ }^{\mathrm{a}}$, James O'Toole ${ }^{\mathrm{a}}$, Gerry Galvin ${ }^{\mathrm{a}}$, Mark O' Callaghan ${ }^{\text {a }}$, Ken Conroy ${ }^{\text {a }}$, Darran Killian ${ }^{\text {a }}$, Tommy Shryane ${ }^{\text {a }}$, Francis Hughes ${ }^{\text {a }}$, Katherine Walsh a, Emily Kavanagh ${ }^{\text {a }}$

${ }^{a}$ Irish Water, Colville House, Talbot Street, Dublin 1, Ireland

${ }^{\mathrm{b}}$ Ulster University, Cromore Road, Coleraine, Co. Londonderry, BT52 1SA, UK

\begin{abstract}
While performance assessments of constructed wetlands sites around the world have appraised their capacity for effective removal of organics, a large variance remains in these sites' reported ability to retain nutrients, which appears to depend on differences in design, operation and climate factors. Nutrient retention is a very important objective for constructed wetlands, to avoid eutrophication of aquatic environments receiving their effluents. This study assessed the performance of constructed wetlands in terms of nutrient retention and associated parameters under the humid conditions of Ireland's temperate maritime climate. A review of the performance of 52 constructed wetland sites from 17 local authorities aimed to identify the best performing types of constructed wetlands and the treatment factors determining successful compliance with environmental standards. Data analysis compared effluent results from constructed wetlands with secondary free surface flow or tertiary horizontal subsurface flow, hybrid systems and integrated constructed wetlands with those from small-scale mechanical wastewater treatment plants of the same size class. Nutrient concentrations in effluents of constructed wetlands were negatively correlated $(\mathrm{p}<0.01)$ with specific area, i.e. the ratio of surface area and population equivalents. The latest generation of integrated constructed wetlands, which had applied design guidelines issued by the Department of the Environment, performed best. Storm management design features improved treatment performance of constructed wetlands significantly $(p<0.05)$ for total suspended solids concentrations and exceedance frequency of limit values for total nitrogen. Mechanical wastewater treatment plants, secondary free surface water and tertiary horizontal subsurface flow wetlands showed a very large variance in effluent concentrations for organic and nutrient parameters. E. coli numbers in effluents were lowest for integrated constructed wetlands with an arithmetic mean of $89 \mathrm{MPN} / 100 \mathrm{ml}$. Despite Ireland's humid climate, some constructed wetland sites achieved long or frequent periods of zero effluent discharge and thus did not transfer any waterborne pollution to their receptors during these periods.
\end{abstract}




\section{Keywords:}

1. Constructed wetlands

2. Wastewater Treatment

3. Water quality

4. Phosphorus

5. Nitrogen

6. Storm management

7. Specific area

\section{Highlights}

1. Integrated constructed wetlands achieved the lowest nutrient concentrations in effluents among constructed wetlands.

2. Specific area (surface area / population equivalents) had a significant impact on effluent quality of tertiary horizontal subsurface flow wetlands

3. Storm management had a significant impact on effluent quality of constructed wetlands.

4. Individual integrated constructed wetlands and hybrid systems achieved optimal outcomes through long periods of zero effluent discharge.

\section{Acronyms}

CW: Constructed Wetlands

DOE: Department of the Environment

ELV: Emission Limit Value

EPA: Environmental Protection Agency in the Republic of Ireland

FSFW: Free Surface Flow Wetland

HSSF Horizontal Subsurface Flow

ICW: Integrated Constructed Wetlands

PE: Population Equivalent

SSF: Subsurface Flow

VSSF: Vertical Subsurface Flow 


\section{Introduction}

Provision of economically and environmentally sustainable wastewater treatment for small communities remains a great challenge all over Europe, but particularly so in countries with large numbers of small and scattered settlements like Ireland. In recent reviews of Irish wastewater licensing 515 authorisations were issued for settlements with less than 500 population equivalents (PE) and a further 359 for settlements with 500-2000 PE (EPA, 2012,2014). A very high failure rate with 37\% of tested licensed agglomerations in a 2014 survey highlighted the challenge in striving for compliance of mechanical small scale wastewater treatment plants with treatment standards for the >2000 PE licensed category (EPA, 2014). Constructed wetlands (CW) may offer an economically feasible solution for this problem.

All municipal CWs in Ireland are operating under the Wastewater Discharge (Authorisation) Regulations (Department of the Environment, Heritage and Local Government, 2007). According to Article 2 in the Wastewater Discharge Regulations, CW operation must satisfy the objectives of the EU Water Framework Directive and associated legislation (Department of the Environment, Housing and Local Government, 2009). The implementation of the Wastewater Discharge Regulations supports the Water Framework Directive's goal to achieve good ecological status in all water bodies. The Environmental Protection Agency (EPA) sets emission limit values for wastewater treatment plants in consideration of this long-term requirement to achieve good status in the receiving water body or according to its designation. Emission limit values on organic pollutants, nutrients and, in some cases, bacteria concentrations in wastewater effluent are licensed under the Wastewater Discharge Regulations 2007. In regard to operational and maintenance costs CWs compare favourably to mechanical wastewater treatment plants (United States Environmental Protection Agency, 1999; Haberl, 1999; Gopal, 1999; Bialowiec et al., 2014; Wu et al., 2014). Based on a whole life cycle assessment Doody et al. (2009) estimated savings of 50\% for capital costs and approximately $90 \%$ for operation and maintenance of $\mathrm{CW}$ systems in comparison to mechanical activated sludge, attached media and membrane plants. This estimate rested on the assumption that the necessary land was available at a reasonable purchase price or that it was possible to negotiate reasonable leasing arrangements. For continuous optimisation of $\mathrm{CW}$ technology through adaption to specific regional conditions, it is necessary to gather data pertaining to the operation, maintenance and performance, in order to inform design and future investment decisions. Two examples of successful projects of this kind already exist in the United States and the United Kingdom. The United States Environmental Protection Agency has compiled the North American Wetlands for Water Quality Treatment Database (NADB), which e.g. contains data on flow, dimensions, plant species and analysis results for samples from influent and effluent water from several hundred locations in the United States and Canada. This information has been utilised to assess constructed wetlands as a treatment alternative to inadequate mechanical wastewater treatment for small communities (United States Environmental Protection Agency, 1999). The United Kingdom's Constructed Wetlands Association formed in response to malpractice of unscrupulous contractors; it maintains a frequently updated $\mathrm{CW}$ database containing information on more than 900 beds in the United Kingdom (Cooper, 2007). As in many other countries, publicly available CW reference data are still scarce in Ireland. This lack of detailed information on design standards and often spurious performance claims by manufacturers reflect badly on regulation and public opinion. Under such circumstances, apprehension to considering CWs as a realistic alternative to mechanical wastewater treatment is not surprising (Babatunde et al., 2007). It is also uncertain to 
what extent decision makers can take guidance from performance data available from other countries, because the true scale of impacts on $\mathrm{CW}$ performance by climatic and specific regional conditions remains to be investigated. Babatunde et al. (2007) therefore recommended the compilation of country specific databases with dimension, operational and performance data on CWs, in order to avoid repetition of design errors. This study aims to fill that knowledge gap for Ireland by providing a first comparative assessment of CW performance for this part of Western Europe, whose temperate maritime climate is characterised by annual average rainfalls of $1230 \mathrm{~mm}$ and whose mean annual air temperatures range between 9 and $10{ }^{\circ} \mathrm{C}$ (Walsh, 2012). While a very small annual water deficit, i.e. the difference between potential and actual evaporation, can accumulate in the summer months, it typically only amounts to less than $15 \mathrm{~mm}$ (Mills, 2000).

The research objectives were:

1. Effluent assessment of $\mathrm{CW}$ categories in comparison to mechanical plants

2. Identification of preferential conditions for nutrient removal

3. Investigation of impacts from storm control on effluent quality

4. Comparison of faecal indicator bacteria numbers in $\mathrm{CW}$ effluents

The research entailed the following stages:

\section{Methods and Materials}

- Identification of sites

- Data gathering

- Data analysis

\subsection{Location of Investigated Sites.}

There are 52 municipal CWs located in 17 local authorities in Ireland, 44\% of CWs are located in two counties, Waterford and Wexford (South East). Fig. 1 illustrates the distribution of CWs around Ireland. Only 55\% of local authorities have adopted the technology. These 52 sites represent $10 \%$ of all existing 515 Irish wastewater treatment sites under $500 \mathrm{PE}$ and $6 \%$ of such sites under $2000 \mathrm{PE}$. 


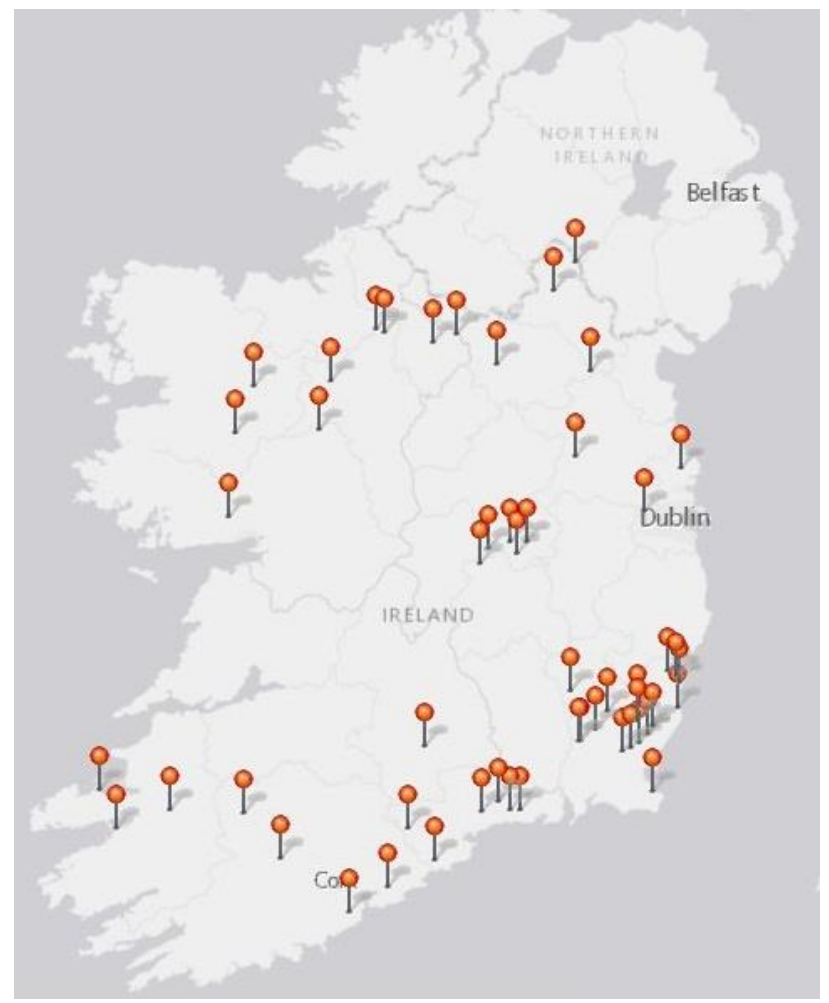

Figure 1: Surveyed municipal Constructed Wetland sites in Ireland

\subsection{Types of the considered designs}

There are three main types of CWs treating municipal wastewater in Ireland:

1. Horizontal subsurface flow (HSSF)

2. Free Surface Flow Wetlands (FSFW) which include Integrated Constructed Wetlands (ICW)

3. Hybrid with a combination of HSSF, vertical subsurface flow (VSSF) and willow

Table 1: Total number of CWs per category

\begin{tabular}{|c|c|c|c|c|c|c|c|}
\hline Category & $\begin{array}{c}\text { Tertiary } \\
\text { HSSF }\end{array}$ & $\begin{array}{c}\text { Tertiary } \\
\text { FSFW }\end{array}$ & ICW & $\begin{array}{c}\text { Secondary } \\
\text { FSFW }\end{array}$ & $\begin{array}{c}\text { Secondary } \\
\text { HSSF }\end{array}$ & $\begin{array}{c}\text { Tertiary } \\
\text { Grass }\end{array}$ & Hybrid \\
\hline Total & 35 & 1 & 6 & 6 & 1 & 1 & 2 \\
\hline
\end{tabular}




\subsubsection{Horizontal Subsurface Flow}

In Ireland, tertiary HSSF systems are the most common CW type for the treatment of municipal wastewater (Table 1). They are characterised by a horizontal wastewater flow path through a permeable medium with a reed bed monoculture (Zhang et al., 2014). Site layout is typically rectangular, and most of these systems are tasked with tertiary polishing of mechanically treated wastewater. They utilise anaerobic, anoxic and to a lesser extent aerobic processes in the degradation of organic matter. The restricted oxygen availability limits aerobic degradation. While this inhibits the CWs' nitrification capability, it does favour denitrification. This preference is mainly due to continuous water saturation, where anoxic and anaerobic conditions prevail throughout most of the bed substrate (Vymazal, 2009). Aerobic degradation is therefore restricted to the rhizome periphery and a thin layer close to the bed surface (Vymazal, 2001). The relatively high phosphorus removal rate of HSSF systems can also be attributed to the almost continuous water saturation of the bed substrate and the thus relatively constant redox potential therein (Zhang et al., 2014).

\subsubsection{Vertical Subsurface Flow}

Similar to HSSF, the VSSF systems are typically rectangular shaped. Wastewater takes a vertical flow path through the solid media before its collection in bottom drainage pipework and transfer to the receptor. Energy and maintenance demands of VSSF systems are higher in comparison, because pumping is required to achieve the necessary intermittent nature of the wastewater distribution (Wu et al., 2014). Only two VSSF sites were part of this study and their results contributed to the category of hybrid systems with reed beds. VSSF CWs provide preferential conditions for nitrification as the intermittent nature of their wastewater distribution sucks air into the beds and thus increases oxygen availability (Vymazal, 2009).

\subsubsection{Hybrid Systems}

Hybrid systems utilise both types of SSF CW in combination. Based on the Max Planck Institute Process the most frequently used hybrid systems entail a VSSF compartment followed by a HSSF compartment (Vymazal, 2013a). The two hybrid systems in this research have that configuration and possess additional willow beds as the final polishing step. Their treatment performance data were part of an earlier assessment by O'Hogain and McCarton (2010) based on a two-year analysis of influent and effluent quality. One system had achieved zero discharge throughout the entire investigation period, while the other only discharged after a period of very heavy rainfall, which made its inflow rise to a value of twenty times its dry weather flow.

\subsubsection{Free Water Surface Flow Wetlands}

FSFW resemble natural wetlands with emergent vegetation, varying water depths and inlet structures designed to provide an even distribution of water (United States Environmental Protection Agency, 1999). Typical FSFW sites have a shallow depth of water (200 mm-300 mm) containing rooted emergent macrophytes (Vymazal, 2013a). The first Irish site has been established in 1990. Some of the twelve FSFW wetlands in this study have reed beds whose outlines represent engineered rectangular systems, while ICWs fit into the landscape as cells with oval shapes for a more natural look. FSFW systems are characterised by relatively large specific surface areas with several macrophyte species. They mimic natural wetland systems and are thus 
providing greater biological complexity and longer hydraulic residence time than other wetland systems.

\subsection{Data gathering}

The survey intended to analyse impacts of CW design parameters. First of all the survey sought to characterise, whether systems were designed to provide secondary or tertiary treatment. Storm management was perceived as an important design feature, because its absence could expose CW sites to hydraulic overloading with a mixture of run-off and wastewater. Beyond that, data compilation considered parameters reflecting $\mathrm{CW}$ size and spatial organisation. Specific area as an important size parameter relates wetland surface area with the wastewater load by calculating a ratio of surface area to population equivalents. Spatial organisation determines the flow of the wastewater stream within the constructed wetland and thus the effective hydraulic retention time. 'Aspect' as the length to width ratio or the number of ponds in sequence is also a useful parameter in this respect. Considering the manifold functions of plants in CW systems, treatment performance may depend on macrophyte diversity to a certain extent. Therefore, this survey differentiated between single reed and multispecies assemblages. The type of bed medium in a $\mathrm{CW}$ has an impact on filtration, adsorption and hydraulic retention time, which depend on the bed material's chemical composition, grain size and sorting of grain sizes. With increasing $\mathrm{CW}$ age, long-term capacity limits may begin to impair effluent quality through effects like clogging or exhaustion of available adsorption sites on the bed material, hence it was also of interest to record the length of time $\mathrm{CW}$ sites had been in operation.

\subsection{Data analysis}

Missing data were replaced with substituted values from available records of licence applications to the Irish EPA and from applications of geographical information systems. Data for hybrid CW systems were taken from O'Hogain and McCarton (2010) with author permission. Some sites were excluded from the analysis due to the validity of the data. After clean up, the dataset thus comprised $44 \mathrm{CW}$ sites and 36 mechanical plants, all of which fulfilled the data quality criteria for inclusion in the statistical analysis. The mechanical category included treatment plants with activated sludge, trickling filter, rotating biological contactor and sequence batch reactors. Influent and effluent results from mechanical plants of the same PE range were compiled from records on the Environmental Data Exchange Network provided by the Irish EPA, in order to compare $\mathrm{CW}$ categories against mechanical systems. Selection criteria for mechanical treatment sites were the existence of a tertiary treatment step with chemical phosphorus removal and a loading of less than $500 \mathrm{PE}$ to allow for comparison with CWs in the same category.

The ICW category was subdivided into two groups; sites, whose completion had predated the issue of design guidelines, were denoted as ICW, and those sites, which were completed after those guidelines had become available, were denoted as ICW DOE (Department of the Environment, Heritage and Local Government, 2010). Storm management categories differentiated whether a constructed wetland had to deal with storm flows or not. Statistical data analysiswas conducted with SPSS and MS EXCEL. Relationships between effluent results, specific area $\mathrm{m}^{2} / \mathrm{PE}$, storm management, age and aspect ratio of the CWs were analysed with 
Spearman rank tests as correlation statistics. Relative emission limit value exceedance frequencies were compared for subgroups of $\mathrm{CW}$ sites and the statistical significance of differences was tested with the Marascuilo procedure or a two-tailed $\chi^{2}$-test. For a comparison of CW categories and mechanical treatment plants effluent data were analysed in SPSS for assessment of the parameters biological oxygen demand, chemical oxygen demand, suspended solids, Orthophosphate-P, total phosphorus, total nitrogen and ammonia nitrogen. The Shapiro Wilks test was utilised to ascertain if normality applied, then the test was bootstrapped in SPSS for a more reliable model for non-normality tests. Pollutant concentrations in effluents were subjected to the KruskalWallis test. Posthoc tests were carried out as pairwise comparisons with Bonferroni corrections. The applied level of significance was 0.05 (two-sided tests). All available data for bacteria numbers in effluents were obtained from local authorities and the Environmental Data Exchange Network. Effluent results from 18 mechanical wastewater treatment plants and $8 \mathrm{CWs}$ were analysed to compare arithmetic means.

\section{Results}

\subsection{Comparison of effluent quality of considered design categories}

Figure 2 shows box plots for the pollutant concentrations in effluents of different categories of treatment, and Table 2 compiles their arithmetic means and standard deviations.

Table 2: Arithmetic means \pm standard deviations of pollutant concentrations (mg/l) in effluents for different treatment categories in the survey

\begin{tabular}{|l|c|c|c|c|c|c|}
\hline Parameter & Secondary FSFW & HSSF Tertiary & Hybrid & ICW & ICW DOE & Mechanical plants \\
\hline BOD & $28.4 \pm 49.4$ & $11.8 \pm 28.2$ & $7.5 \pm 11.1$ & $3.7 \pm 3.4$ & $3.3 \pm 2.4$ & $8.8 \pm 14.2$ \\
\hline COD & $82.2 \pm 96.9$ & $46.5 \pm 65.0$ & $31.5 \pm 21.7$ & $48.1 \pm 24.3$ & $27.9 \pm 14.2$ & $44.7 \pm 56.7$ \\
\hline TSS & $46.4 \pm 171.3$ & $19.4 \pm 39.0$ & $14.0 \pm 18.3$ & $5.3 \pm 4.8$ & $6.0 \pm 4.8$ & $20.1 \pm 42.3$ \\
\hline Ammonia-N & $6.7 \pm 8.3$ & $10.4 \pm 15.5$ & $7.6 \pm 9.8$ & $2.4 \pm 3.3$ & $0.8 \pm 1.5$ & $4.4 \pm 10.4$ \\
\hline TN & $20.5 \pm 9.3$ & $20.3 \pm 19.5$ & $12.5 \pm 14.0$ & $6.7 \pm 10.4$ & $2.7 \pm 2.0$ & $22.5 \pm 29.6$ \\
\hline Orthophosphate -P & $3.5 \pm 2.6$ & $3.7 \pm 4.3$ & $2.4 \pm 1.5$ & $1.8 \pm 1.3$ & $0.2 \pm 0.2$ & $1.5 \pm 6.9$ \\
\hline TP & $3.8 \pm 2.1$ & $4.6 \pm 4.6$ & $2.8 \pm 2.1$ & $1.6 \pm 2.1$ & $0.3 \pm 0.2$ & $1.5 \pm 2.0$ \\
\hline
\end{tabular}

\subsubsection{Biological and chemical oxygen demand}

In Table 2 and Figure 2, ICW and ICW DOE effluents had the lowest biological oxygen demand concentrations. Figure 2 also displays a high number of outliers for mechanical plants and tertiary HSSF, indicating extremely high concentrations compared to emission limit values and to median values for the respective categories. This would also indicate frequent problems with effluent quality. Particularly noteworthy is a partial exceedance of the indicative $25 \mathrm{mg} / \mathrm{l}$ biological oxygen demand Emission Limit Value by the upper quartile of secondary FSFW effluent values, which indicates frequent problems in this category to comply with this commonly set ELV for biological oxygen demand 
The Kruskal Wallis test $(\mathrm{H}(5)=46.728, \mathrm{p}<0.001)$ revealed a significant difference between treatment categories for biological oxygen demand values in effluents. Posthoc tests for pairwise comparisons confirmed significant differences between secondary FSFW and all other categories (Table 3). Differences were also significant between categories ICW and mechanical plants $(\mathrm{p}=0.002)$ and between ICW and tertiary HSSF $(\mathrm{p}=0.014)$. Analysis of chemical oxygen demand values showed a similar pattern in the Kruskal Wallis test $(H(5)=46.807, \mathrm{p}<0.001)$ and in pairwise comparisons, again with secondary FSFW as the worst performing category in terms of exceedance frequency for a commonly applied $125 \mathrm{mg} / \mathrm{l} \mathrm{emission} \mathrm{limit} \mathrm{value.} \mathrm{Effluent} \mathrm{results} \mathrm{for}$ this treatment category were significantly different from all others (Table 3).

\subsubsection{Total suspended solids}

In Figure 2 ICW DOE and ICW systems were the only categories without exceedances for $35 \mathrm{mg} / \mathrm{l}$ total suspended solids as a common emission limit value. Secondary FSFW results spanned the widest range; effluent concentrations from mechanical and tertiary HSSF systems also ranged widely with high proportions of limit value exceedances.

In the Kruskal Wallis test there were significant differences between categories for total suspended solids concentrations in effluents $(\mathrm{H}(5)=76.120, \mathrm{p}<0.001)$. Pairwise analysis showed significant differences for any pairing between a category from the group ICW DOE and ICW with any of the categories secondary FSFW systems, mechanical plants and tertiary HSSF (Table $3)$. 

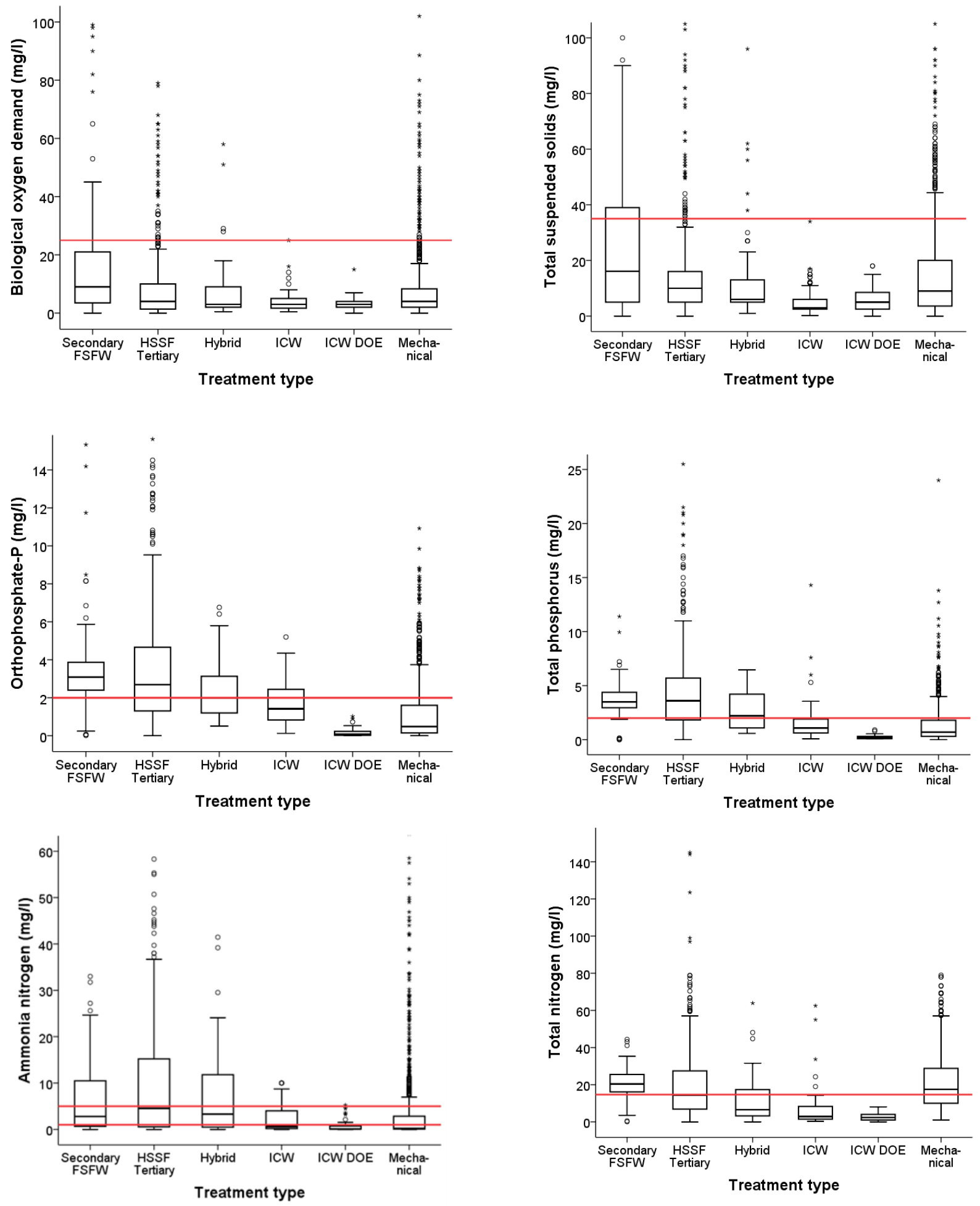

Figure 2: Tukey style box-whisker plots for effluent concentrations of biological oxygen demand, total suspended solids, orthophosphate-P, total phosphorus, ammonia-nitrogen and total nitrogen concentrations across categories of wastewater treatment plants with indicative reference lines for commonly applied environmental limit values. 


\subsubsection{Orthophosphate-P}

The $2 \mathrm{mg} / \mathrm{l}$ line in the orthophosphate-P plot in Figure 2 represents a common emission limit value. Effluent concentrations in all categories except for ICW DOE frequently exceeded this limit, particularly secondary FSFW with more than $75 \%$ of all its analysis results. It is also noteworthy that the largest variance and the highest exceedances were recorded for the category tertiary HSSF.

The Kruskal Wallis test $(\mathrm{H}(5)=434.395, \mathrm{p}<0.001)$ revealed that some differences between categories were significant. Pairwise comparisons showed that ICW DOE effluent results were significantly different from all other categories. While there were no significant differences between secondary FSFW and tertiary HSSF, effluent concentrations of these two categories were significantly different from all other categories (Table 3 ).

\subsubsection{Total phosphorus}

TP effluent concentrations for the surveyed categories of treatment sites in Figure 2 mirror the performance pattern described for orthophosphate-P. ICW DOE was the only category without registered emission limit value exceedances, while tertiary HSSF values displayed the largest variance and highest exceedances. With regard to exceedance frequency, the category of secondary FSFW had the worst performance data with all effluent concentrations but one outlier exceeding the $2 \mathrm{mg} / \mathrm{l}$ emission limit value. This may suggest general problems with the ability of this $\mathrm{CW}$ category to retain phosphorus.

The Kruskal Wallis test $(\mathrm{H}(5)=476.863, \mathrm{p}<0.001)$ showed that some differences between categories were significant. In pairwise comparisons, ICW DOE effluent results were significantly different from all other categories (Table 5). Results for mechanical plants and ICW as the next best performing categories were significantly different from secondary FSFW and tertiary HSSF (Table 3).

\subsubsection{Ammonia nitrogen}

Indicative emission limit value lines in Figure 2 provide a reference to compliance of categories with surface water regulations. Ammonia nitrogen concentrations of $1 \mathrm{mg} / \mathrm{l}$ and $5 \mathrm{mg} / \mathrm{l}$ represent lower and higher emission limit values depending on individual licensing conditions. While all categories transgressed the lower limit, only effluent concentrations from ICW DOE systems did not exceed the $5 \mathrm{mg} / \mathrm{l}$ limit. High numbers of outliers, exceeding the $5 \mathrm{mg} / \mathrm{l}$ emission limit value band, for mechanical treatment plants and a large variance with a high proportion of exceedances were evident in the categories secondary FSFW, tertiary HSSF and hybrid systems.

The Kruskal Wallis test $(\mathrm{H}(5)=202.058, \mathrm{p}<0.001)$ revealed significant differences between categories. Pairwise comparisons showed that there were significant differences between ICW DOE and other categories, with the exceptions of differences to ICW and mechanical plants (Table 3).

\subsubsection{Total nitrogen}

Both ICW categories achieved low total nitrogen concentrations in their effluents, but only ICW DOE had no exceedance of the $15 \mathrm{mg} / \mathrm{l}$ concentration commonly set as an emission limit value for total nitrogen (Figure 2). Effluent concentrations for other treatment categories were typically an order of magnitude higher (Table 2). Hybrid systems still performed relatively favourably with most of their upper quartile not exceeding the indicative emission limit value. 
The Kruskal Wallis test $(\mathrm{H}(5)=201.584, \mathrm{p}<0.001)$ showed that there were significant differences between categories. In pairwise comparisons ICW and ICW DOE had significant differences to categories secondary FSFW, mechanical plants and tertiary HSSF, but only ICW DOE effluent values were significantly lower than those of hybrid systems (Table 3).

Table 3: Adjusted probabilities after Bonferroni correction for pairwise comparisons as posthoc tests for the Kruskal-Wallis test of effluent concentrations in different treatment categories. (Asterisks mark significant differences between two categories.)

\begin{tabular}{|l|c|c|c|c|c|c|c|}
\hline & \multicolumn{9}{|c|}{ Parameters } \\
\hline Categories & $\begin{array}{c}\text { Biological } \\
\text { oxygen } \\
\text { demand }\end{array}$ & $\begin{array}{c}\text { Chemical } \\
\text { oxygen } \\
\text { demand }\end{array}$ & $\begin{array}{c}\text { Total } \\
\text { suspended } \\
\text { solids }\end{array}$ & $\begin{array}{c}\text { Orthophos } \\
\text { phate-P }\end{array}$ & $\begin{array}{c}\text { Total } \\
\text { phosphorus }\end{array}$ & $\begin{array}{c}\text { Ammonia } \\
\text { nitrogen }\end{array}$ & $\begin{array}{c}\text { Total } \\
\text { nitrogen }\end{array}$ \\
\hline ICW - ICW DOE & $>0.999$ & $0.001^{*}$ & $>0.999$ & $<0.001^{*}$ & $<0.001^{*}$ & 0.120 & $>0.999$ \\
\hline ICW - Hybrid & $>0.999$ & $0.001^{*}$ & $0.003^{*}$ & $>0.999$ & 0.416 & 0.128 & 0.092 \\
\hline ICW - Mechanical & $0.002^{*}$ & $<0.001^{*}$ & $<0.001^{*}$ & $<0.001^{*}$ & $>0.999$ & $>0.999$ & $<0.001^{*}$ \\
\hline ICW - HSSF Tertiary & $0.014^{*}$ & $<0.001^{*}$ & $<0.001^{*}$ & $0.016^{*}$ & $<0.001^{*}$ & $<0.001^{*}$ & $<0.001^{*}$ \\
\hline ICW - Secondary FSFW & $<0.001^{*}$ & $>0.999$ & $<0.001^{*}$ & $0.013^{*}$ & $<0.001^{*}$ & $0.025^{*}$ & $<0.001^{*}$ \\
\hline ICW DOE - Hybrid & $>0.999$ & $>0.999$ & 0.368 & $<0.001^{*}$ & $<0.001^{*}$ & $<0.001^{*}$ & $0.002^{*}$ \\
\hline ICW DOE - Mechanical & $0.304^{*}$ & $>0.999$ & $0.025^{*}$ & $<0.001^{*}$ & $<0.001^{*}$ & 0.324 & $<0.001^{*}$ \\
\hline ICW DOE - HSSF Tertiary & 0.582 & $>0.999$ & $0.019^{*}$ & $<0.001^{*}$ & $<0.001^{*}$ & $<0.001^{*}$ & $<0.001^{*}$ \\
\hline ICW DOE - Secondary FSFW & $<0.001^{*}$ & $0.009^{*}$ & $<0.001^{*}$ & $<0.001^{*}$ & $<0.001^{*}$ & $<0.001^{*}$ & $<0.001^{*}$ \\
\hline Hybrid - Mechanical & $>0.999$ & $>0.999$ & $>0.999$ & $<0.001^{*}$ & $0.018^{*}$ & $<0.001^{*}$ & $<0.001^{*}$ \\
\hline Hybrid - HSSF Tertiary & $>0.999$ & $>0.999$ & $>0.999$ & $>0.999$ & $>0.999$ & $>0.999$ & $0.009^{*}$ \\
\hline Hybrid - Secondary FSFW & $0.011^{*}$ & $0.011^{*}$ & 0.070 & $>0.999$ & $>0.999$ & $>0.999$ & $<0.009^{*}$ \\
\hline Mechanical - HSSF Tertiary & $>0.999$ & $>0.999$ & $>0.999$ & $<0.001^{*}$ & $<0.009^{*}$ & $<0.001^{*}$ & $0.008^{*}$ \\
\hline Mechanical - Secondary FSFW & $<0.001^{*}$ & $0.002^{*}$ & $0.001^{*}$ & $<0.001^{*}$ & $<0.001^{*}$ & $<0.001^{*}$ & $>0.999$ \\
\hline HSSF Tertiary - Secondary FSFW & $<0.001^{*}$ & $<0.001^{*}$ & $0.003^{*}$ & $>0.999$ & $>0.999$ & $>0.999$ & 0.286 \\
\hline
\end{tabular}

\subsection{Impacts of the specific area metric and macrophyte diversity on $\mathrm{CW}$ effluent quality}

Spearman rank correlations between specific surface area and pollutant concentration in effluents were negative and significant $(\mathrm{p}<0.01)$ for total nitrogen, ammonia nitrogen, total phosphorus and orthophosphate-P. Correlations for total phosphorus, orthophosphate-P and total nitrogen were of moderate strength $(\mathrm{r}=0.40-0.59)$; for ammonia nitrogen the correlation was weak $(r=0.2-0.3)$. For biological oxygen demand, suspended solids and chemical oxygen demand correlations were very weak $(r=0.00-0.19)$ and not statistically significant. The sites in CW categories tertiary HSSF and secondary FSFW had sufficiently wide ranges for the design metric specific area and an appropriately even distribution across this range to enable a comparison of emission limit value exceedance rates after grouping of sites within these categories according to specific area. For tertiary HSSF exceedance rates for total phosphorus and orthophosphate-P dropped sharply for specific area values $\geq 4 \mathrm{~m}^{2} / \mathrm{PE}$; the latter group was significantly different from all others $(\mathrm{p}=0.001)$, when the Marascuilo procedure was applied. For total nitrogen exceedance rates dropped sharply for specific area values $>3 \mathrm{~m}^{2} / \mathrm{PE}$ and the two groups representing larger values of the specific area metric were significantly different from all others $(\mathrm{p}=0.001)$, when applying the Marascuilo procedure. Together with the large variance of effluent results, the described sharp drops provide partial explanations for the low correlation coefficients. 
A comparison of concentrations between effluents from sites with either a mixed macrophyte assemblage or a single reed species with the Mann Whitney $U$ test showed a significant difference $(\mathrm{p}<0.05)$ for all parameters. However, the circumstance, that all sites with mixed macrophyte assemblages belonged to the ICW category and therefore also had high values for the specific area metric, compounded the difficulty in interpreting this result.

\subsection{Storm management}

Table 4 compares effluent concentrations from CW sites with and without storm management. When total suspended solids effluent concentrations were compared, a Mann Whitney U test (U=42121, $\mathrm{n}_{1}=95, \mathrm{n}_{2}=769, \mathrm{p}<0.05$ two-tailed) showed a statistically significant difference $(\mathrm{p}=0.015)$ between median values from sites with and without storm management, However, when the test was applied to other parameters differences between those groups of sites were not significant. The Levene test showed a significant difference $(p<0.05)$ in variance between effluent concentrations at sites with storm and without storm management for chemical oxygen demand, total phosphorus and ammonia nitrogen; total nitrogen and orthophosphate-P missed the significance threshold only narrowly with $\mathrm{p}=0.050$ and $\mathrm{p}=0.051$ respectively. Emission limit value exceedance frequencies were compared with a two-tailed $\chi^{2}$-test. For total nitrogen there was a significant difference $(\mathrm{p}=0.015)$ between sites with $(25 \%$ exceedance $)$ and without storm management ( $42 \%$ exceedance).

Table 4: Arithmetic means \pm standard deviations of pollutant concentration $(\mathrm{mg} / \mathrm{l})$ in effluents of sites with and without storm control

\begin{tabular}{|l|c|c|}
\hline Parameter & Storm management & No storm management \\
\hline $\begin{array}{l}\text { Biological oxygen } \\
\text { demand }\end{array}$ & $9.3 \pm 13.0$ & $11.4 \pm 26.4$ \\
\hline $\begin{array}{l}\text { Chemical oxygen } \\
\text { demand }\end{array}$ & $40.3 \pm 33.1$ & $47.7 \pm 57.7$ \\
\hline $\begin{array}{l}\text { Total suspended } \\
\text { solids }\end{array}$ & $11.5 \pm 16.7$ & $20.6 \pm 74.1$ \\
\hline Ammonia-nitrogen & $6.2 \pm 7.5$ & $8.7 \pm 14.0$ \\
\hline Total nitrogen & $10.7 \pm 7.9$ & $17.5 \pm 18.2$ \\
\hline Orthophosphate -P & $2.1 \pm 1.3$ & $3.2 \pm 3.8$ \\
\hline Total phosphorus & $2.8 \pm 1.9$ & $4.2 \pm 4.4$ \\
\hline
\end{tabular}

\subsection{Seasonal differences in performance of constructed wetlands}

Kruskal Wallis analysis of all CW categories indicated statistically significant differences between seasons for the parameters ammonia nitrogen, total suspended solids and chemical oxygen demand.

For all three parameters, seasonal arithmetic means and variance were highest in the autumn months After Bonferroni corrections, pairwise comparisons did not confirm significant seasonal differences for chemical oxygen demand. However, for ammonia nitrogen seasonal differences 
were significant between spring and winter $(\mathrm{p}=0.006)$; for total suspended solids spring-autumn $(\mathrm{p}=0.003)$ and spring-winter differences were significant $(\mathrm{p}<0.017)$.

\subsection{Removal of bacteria}

Compared to the mechanical plants the ICW and HSSF systems had lower E. coli effluent concentrations, however in some instances the sample size for the statistics were low, more data would be needed to confirm the results. ICW had a mean MPN/100ml concentration of $0.9 \times 10^{1}$, Secondary HSSF systems had mean concentrations of $4.6 \times 10^{3}$ while conventional activated sludge plants with UV equipment had concentrations of $2.1 \times 10^{4}$.

\section{Discussion}

This study represents the most extensive comparison of CW sites in Ireland thus far, and it has endeavoured to include all suitable $\mathrm{CW}$ sites in existence at the time of survey. Due to differences in popularity of individual design concepts, the numbers of sites within individual CW categories were highly variable. This imposed limitations on the data analysis, in order to minimise the risk of drawing conclusions from observed differences, which may only have occurred by chance. Nitrogen removal appears to be the greatest challenge for mechanical plants. In particular, total nitrogen effluent concentrations from mechanical plants with anoxic selectors were highly variable. This is surprising, because the treatment control features actually provide an environment favourable for denitrification. However, anoxic selectors for plants with small wastewaters loads make the operation of these treatment plants more complex. Potential explanations for the episodically low performance in this category are that the small systems of this complexity have difficulties in coping with peak flows, which are highly oxygenated.

Effluent data from tertiary HSSF, secondary FSFW and hybrid systems in this study exhibited very high variance and displayed relatively high arithmetic means for nutrient concentrations. One of the reasons for the poor performance could be the typically lower specific area metric of these systems. Internationally, regulations and recommendations vary considerably regarding the necessary specific areas to achieve adequate treatment outcomes. The Department of the Environment, Heritage and Local Government (2007) has published guidelines for ICWs in Ireland. These guidelines stipulated $20 \mathrm{~m}^{2} / \mathrm{PE}$ for wastewater systems with no surface water input and $40 \mathrm{~m}^{2} / \mathrm{PE}$ for combined systems receiving surface water and wastewater effluents were set to provide sufficient capacity for adequate phosphorus retention.

CW systems with smaller sizes have usually been licensed, where removal of organics was the only objective. Cooper (1990) prescribed a minimum specific area of at least $5 \mathrm{~m}^{2} / \mathrm{PE}$, while Kickuth (1977) had recommended $2 \mathrm{~m}^{2} / \mathrm{PE}$ for reed bed systems as the secondary treatment step. However, after implementation of the Water Framework Directive, nutrient standards have become much more prevalent and $\mathrm{CW}$ design should therefore accommodate them. Babatunde et al. (2007) noted that recommendations for specific area varied depending on treatment with suggested values of $10 \mathrm{~m}^{2} / \mathrm{PE}$ and $5 \mathrm{~m}^{2} / \mathrm{PE}$ for secondary and tertiary treatment respectively. Vymazal (2005) stated however, that $5 \mathrm{~m}^{2} / \mathrm{PE}$ was generally insufficient for nutrient removal. 
For tertiary HSSF systems in Ireland this study has confirmed that a metric of $>4 \mathrm{~m}^{2} / \mathrm{PE}$ appears to result in significantly lower exceedance rates for three of the monitored nutrient parameters, which is important as phosphorus typically is the limiting nutrient for freshwater systems. However, there was no conclusive evidence for a similar threshold with regard to ammonia nitrogen in this category. This may suggest inhibition of nitrification by oxygen depletion or low $\mathrm{pH}$. Constant saturation of bed media with wastewater can lead to low nitrification/denitrification efficiency, which would explain why HSSF with specific area values $<1 \mathrm{~m}^{2}$ had a significantly higher exceedance frequency than all other groups in this category. The high variability of effluent concentrations of tertiary HSSF systems may be a consequence of inadequate treatment by the upfront mechanical plants, which may lead to overloading of CW systems. Brix (1994) described how malfunctioning of upfront mechanical plants can cause clogging effects in tertiary systems. High loads of total suspended solids (United States Environmental Protection Agency, 1999), organics and nutrients, either clog the bed material themselves or feed excessive microbial growth to the same effect. Clogging of subsurface gravel based CW systems is a common problem over the lifespan of operation, causing surface flow (Wu et al., 2014) or a stark increase of transfers through preferential flow paths in comparison to matrix flow. A United Kingdom survey of 255 SSF CWs found that $30 \%$ showed signs of surface flow (Cooper et al., 2008). Knowles et al. (2010) studied a clogged HSSF system and built a three-dimensional hydraulic conductivity profile based on monitoring data from dye tests. Their study found that "preferential flow paths accounted for $80 \%$ of the overall flow and arrived $8 \mathrm{~h}$ before a distinctly separate secondary matrix flow component". Such a scenario obviously decreases the effective hydraulic residence time, in which treatment processes can take place and thus impairs effluent quality. Babatunde et al. (2007) identified clogging as the biggest operational problem for VSSF $\mathrm{CWreed}$ beds and recommended the use of bed media with larger grain size for mitigation. Biological or hydraulic overloading is also likely to be a common issue for small-scale mechanical plants in Ireland as evidenced by the high number of outliers for this category. For secondary FSFW, as the other category warranting statistical analysis of effluent concentrations in groups according to specific area, there was no evidence for lower exceedance frequencies for systems with larger specific area values. This category's narrow range of values for this metric with an arithmetic mean of $7.2 \mathrm{~m}^{2} / \mathrm{PE}$ may be the reason for this observation. Indeed, much larger specific area values have been suggested in conclusion of an extensive CW survey in Denmark, with $30 \mathrm{~m}^{2} / \mathrm{PE}$ for $\mathrm{N}$ removal and $40-70 \mathrm{~m}^{2} / \mathrm{PE}$ for phosphorus removal in secondary systems (Brix and Schierup, 1989). Therefore, dimensions of existing Irish secondary FSFW sites appear to be too small for effective treatment; the majority's specific area metric is far below the national guideline values of $20 \mathrm{~m}^{2} / \mathrm{PE}$ and $40 \mathrm{~m}^{2} / \mathrm{PE}$. ICW performed well for all analysed parameters. With an average for all ICWs in this study of $65 \mathrm{~m}^{2} / \mathrm{PE}$, which is above Department of Environment guidelines, this category's treatment performance finds itself supported by much larger values for the specific area metric than all other systems in this survey. The large metric not only indicates a long hydraulic residence time in these systems, which provides favourable conditions for nitrification to take place, but also suggests a large capacity for adsorption or plant uptake of phosphorus (Valsero et al., 2014). The effects became most apparent in the results of the post guideline ICW category (ICW DOE), which were significantly better than those for most other systems, e.g. for total phosphorus and ammonia nitrogen concentrations in effluents.

With such a large size, ICWs can also absorb water volumes from storm events without pronounced negative effects on effluent quality. In fact, an ICW system has a zero discharge 
element; five ICW sites experienced periods of zero discharge. One site had a recorded 116 days of zero discharge over the whole survey year and discharged 6,500 $\mathrm{m}^{3}(14 \%)$ less from the outfall pipe than it had received through inflow pipes. Evapotranspiration from macrophytes and evaporation from water and bed surfaces account for the difference in water volume. Unfortunately, an annual flow record was only available for a single site in this category, which had been equipped with permanent flow gauges at inflow and outflow locations.

In Ireland, wastewater treatment plants are only required to treat volumes of 3 times dry weather flow with storage or about approximately 6.7 times dry weather flow without storage ('Formula A' in the guidance for storm water, EPA, 1995). This may generate an opportunity to optimise the size of ICWs by designing for 3 times dry weather flow and $20 \mathrm{~m} 2 / \mathrm{PE}$, where space is at a premium, rather than for a treatment of the total volume of water from rainwater and wastewater in sewers, as it is currently the norm. To minimise environmental pollution, this would however require a separation of sewers for rainwater and wastewater and would thus be only be economically feasible in areas with sufficient population density. Hybrid systems performed poorly with regard to total nitrogen, orthophosphate-P and total phosphorus. Yet, their results may actually be better than the data suggest. The sampling scheme for these sites did not adequately reflect the zero discharge element of the process, as effluent samples were collected upstream of the willow plantations, which are the final site element the water has to pass. Records of the two sites with hybrid systems by O'Hogain and McCarton (2010) show that one site continuously had zero discharge, while the other site had zero discharge for long periods of time (10 of 24 sampling days with no flow). At this second site, a recorded storm episode with a volume in excess of 20 times dry weather flow entered the system and subsequently led to elevated nutrient concentrations in the system's discharge, thus highlighting the importance of storm management. Hybrid systems and ICWs represent an opportunity for sites discharging to low assimilative capacity streams, particularly with storm management. High flow conditions can cause $\mathrm{CW}$ scouring resulting in sediment remobilisation and thus high total suspended solids concentrations, which may coincide with elevated nutrient release (Gopal, 1999). Storm management had an impact on results in most categories, but particularly for tertiary HSSF sites, of which $50 \%$ had features of storm control. The analysis of effluent results suggested that storm management not only appears to improve effluent quality significantly in terms of suspended solids concentrations and exceedance frequency for total nitrogen concentrations, but also in terms of predictability, because there was significantly less variance in effluent results for sites with such features. Therefore, the latter could improve $\mathrm{CW}$ performance considerably and thus contribute to better surface water quality. There have been detailed descriptions of the multiple benefits of macrophytes for treatment performance in $\mathrm{CW}$ systems, e.g. contribution to sedimentation through decreased water velocity, aeration and increased hydraulic conductivity in the root zone of bed sediments, provision of bacterial substrates, promotion of microbial processes like nitrification and denitrification and retention of nutrients through their uptake in plant biomass (Vymazal, 2013b). Some studies have also highlighted benefits of different macrophyte assemblages (Debing et al., 2009), but data analysis in this study did not reveal any differences in treatment outcomes that were clearly attributable to the assemblage. Potential explanations are that the measure of macrophyte diversity may have been too crude (single species vs. multispecies) and that the direct effects of plants on treatment outcomes may actually be comparatively small, e.g. the nutrient uptake by plants can be as low as $2 \%$ of the nutrient load (Langergraber, 2005). Public reservations against the treatment of wastewater by CW systems include an expectation that treatment performance would vary with the seasonal cycle, 
e.g. because of the temperature dependence of biological processes like nitrification. The comparison of seasonal means for effluent concentrations across all $\mathrm{CW}$ categories in this study did not reveal many significant differences. Nevertheless, seasonal means and variance tended to be larger in autumn.

Scouring after relatively dry periods and releases from decaying plant matter may provide potential explanations for this observation. Due to the maritime weather influence, seasonal temperature change in Ireland is however fairly moderate and may therefore not lead to very different seasonal treatment outcomes, especially if most of the important treatment processes happen in subsurface environments, where the temperature change is even less pronounced. There is currently no evidence for a loss of CW treatment efficacy during the winter months in Ireland. In spite of limited data availability for faecal indicator bacteria in effluents, it was surprising to note that higher E. coli numbers occurred in the discharge of mechanical treatment plants with UV equipment, whose sole purpose is the deactivation of bacterial cells. This poor level of performance suggests design flaws or maintenance issues of UV treatment systems in small wastewater treatment plants, such as poor clarifier performance or undetected bulb malfunction. Again, ICW systems showed the best performance. Their long hydraulic residence times are not suitable for the survival of intestinal bacteria. Hence, ICWs are unlikely to discharge many faecal microorganisms and thus may represent the treatment system of choice near bathing waters or sites of shellfish production.

\section{Conclusion}

Constructed wetlands and particularly ICW could be utilised more widely in Ireland as a sustainable solution for wastewater treatment of small communities. However, ICW is a relatively new treatment system and more monitoring is needed long term to assess and understand adsorption capacity of phosphorous and nitrification of ammonia. In the investigated size class, CW systems could provide effective alternatives to mechanical treatment plants or complement the latter by providing a tertiary treatment step for effluents from mechanical units. Sites in catchment areas of water bodies with sensitivity towards eutrophication could utilise the hybrid systems for zero discharge. Sites with very restricted space could employ tertiary CWs with storm management. This would increase compliance with environmental standards set by the Water Framework Directive and associated legislation, e.g. the Bathing Water Directive. The poor results for underperforming $\mathrm{CW}$ categories such as tertiary HSSF systems could be attributed to very small specific areas, poorly operated upfront mechanical plants and issues related to storm control. ICW systems appeared to perform well at nutrient retention; this was most apparent for those sites, whose construction followed Department of Environment Housing and Local Government design guidelines. The correct sizing of $\mathrm{CW}$ systems together with appropriate storm management are preconditions for optimal nutrient retention. This requires consideration for the optimisation of current design concepts and for future design ideas. As part of operational and maintenance procedures, dry weather flows need to be estimated for existing sites and storm control features have to be employed, in order to improve performance across all categories including mechanical sites. As an integral part of standard operating procedures, this would be a big step towards identifying and mitigating problems of small wastewater treatment systems in a timely manner. 


\section{Acknowledgments}

We are grateful to Sean O'Hogain and Liam McCarton for permission to use the results from their hybrid systems research, to Rory Harrington for his guidance and help concerning ICW systems, to James O'Toole, Eadaoin Joyce, Mark O'Callaghan, Gerry Galvin, Francis Hughes, Darran Killian, Emily Kavanagh, Martina Duignan and Karen Gallagher in Irish Water and Paul Carroll from Waterford County Council, Leonard Poole and James Rattigan from Wexford County Council for guidance in their fields of expertise. We would like to thank Local Authority staff for their co-operation in the data gathering.

\section{References}

Babatunde, A., Zhao, Y., O’Neill, M. and O’Sullivan, B., 2007. Constructed wetlands for environmental pollution control: a review of developments, research and practice in Ireland. Environment International, 34, 1, 116-126

Bialowiec, A., Albuquerque, A. and Randerson, P., 2014. The influence of evapotranspiration on vertical flow subsurface constructed wetland performance. Ecological Engineering, 67, 89-94

Brix, H., 1994. Use of Constructed Wetlands in Water Pollution Control: Historical Development, Present Status, and Future Perspectives. Water Science and Technology. 30, 8, 209-223

Brix, H., Schierup, H. 1989. Danish experience with sewage treatment in constructed wetlands. In: Hammer, D.A., ed. 1989, Constructed wetlands for wastewater treatment. Lewis publishers, Chelsea, Michigan

Cooper, P., 1990. European Design and Operation Guidelines for reed bed treatment systems. Prepared for the European Water Pollution Control Association, Water Research Centre Publication

Cooper, P., 2007. The Constructed Wetland Association UK database of constructed wetland systems. Water Science and Technology, 56, 3, 1-6

Cooper, D., Griffin, P., Cooper P., 2008. Factors affecting the longevity of sub-surface horizontal flow systems operating as tertiary treatment for sewage effluent. In: Vymazal, J. (ed.), Wastewater treatment, plant dynamics and management in constructed and natural wetlands. Springer, Dordrecht, the Netherlands, 191-198

Debing, J., Lianbi, Z., Xiaosong, Y., Jianming, H., Mengbin, Z., Yuzhong, W., 2009. COD, TN and TP removal of Typha wetland vegetation of different structures. Polish Journal of Environmental Studies, 18, 183-190

Department of the Environment, Heritage and Local Government, 2009. European communities environmental objectives (Surface water) regulations 2009. Available at http://www.irishstatutebook.ie/pdf/2009/en.si.2009.0272.pdf accessed June 2016 
Department of the Environment, Heritage and Local Government, 2010. Integrated constructed wetlands. Available from: URL:

http://www.environ.ie/en/Publications/Environment/Water/FileDownLoad,24931,en.pdf accessed January 2016

Department of the Environment, Heritage and Local Government, 2015. Urban Waste Water Treatment in 2014. Available from http://www.epa.ie/pubs/reports/water/wastewater/2014\%20waste\%20water\%20report_web.pdf

Doody, D., Harrington, R., Johnson M., Hofmann, O. and McEntee, D., 2009. Sewerage treatment in an integrated constructed wetland. Municipal Engineer, 162, 199-205

Environmental Protection Agency. 1995. Urban Wastewater Treatment Directive (91/271/EEC). Procedures and criteria in relation to storm water overflows. Available at http://www.epa.ie/pub/advice/wastewater/UrbanWasteWater2.pdf accessed June 2016

Gopal, B., 1999. Natural and Constructed Wetlands for Wastewater Treatment: Potentials and Problems. Water Science and Technology., 40, 3, 27-35

Haberl, R., 1999. Constructed Wetlands: Chance to Solve Wastewater Problems in Developing Countries. Water, Science and Technology., 40, 3, 11-17

Kickuth, R., 1977. Degradation and incorporation of nutrients from rural wastewaters by plant rhizosphere under limnic conditions. In: Utilization of Manure by Land Spreading. Comm. Europ. Commun., EUR 5672e, London, UK, pp. 335-343.

Knowles, P., Griffin, P., Davies, P., 2010. Complementary methods to investigate the development of clogging within a horizontal sub-surface flow tertiary treatment wetland. Water Research, 44, 320-330

Langergraber, G., 2005. The role of plant uptake on the removal of organic matter and nutrients in subsurface flow constructed wetlands: a simulation study. Water Science and Technology, 51 9, 213-23

Luanaigh, N., Goodhue, R., and Gill, L., 2010. Nutrient removal from on- site domestic wastewater in horizontal subsurface flow reed beds in Ireland. Ecological Engineering, 36, 12661276

Mills, G., 2000. Modelling the water budget of Ireland-evapotranspiration and soil moisture. Irish Geography, 33, 99 - 116

O’Hogain, S. and McCarton, L., 2010. The Operation of hybrid reed bed and willow bed combinations in Ireland- Zero discharge and the potential for no monitoring of domestic application of this combination. Proceedings $2^{\text {nd }}$ International Conference on Constructed Wetlands for Wastewater treatment and environmental pollution control. UCD, Dublin. October 2010 
United Kingdom Water Industry Research, 2011. A review of the setting of iron limits for wastewater treatment works effluents. Available at http://ukwir.forefront-library.com/reports/11ww-20-4/93693/94658/90055,90059/90059 accessed October 2015

United States Environmental Protection Agency Manual,1999. Constructed Wetlands Treatment of Municipal Wastewaters. Available from: water.epa.gov/type/wetlands/.../constructedwetlands-design-manual.pdf

Valsero,M., Matamoros,V.,Cardona, R.,Villacorta, J.,Becares, E and Bayona, J., 2014. Comprenhensive Assessment of the design configuration of constructed wetlands for the removal of personnel care products from urban wastewaters. Water Research 44, 3669-3678

Vymazal, J., 200. Types of constructed wetlands for wastewater treatment: their potential for nutrient removal. In Vymazal, J. (Ed.) Transformations of Nutrients in Natural and Constructed Wetlands. Backhuys Publishers, Leiden, The Netherlands, pp.1-93

Vymazal, J., 2005. Horizontal sub-surface flow and hybrid constructed wetlands systems for wastewater treatment. Ecological Engineering, 25, 478 -490

Vymazal, J., 2007. Removal of nutrients in various types of constructed wetlands. Science of the Total Environment, 380, 48-65

Vymazal, J., 2009. Removal of organics in constructed wetlands with horizontal sub-surface flow: A review of the field experience

Vymazal, J., 2013a. The use of hybrid constructed wetlands for wastewater treatment with special attention to nitrogen removal: A review of a recent development. Water Research, 47, $4795-4811$

Vymazal, J., 2013b. Emergent plants used in free water surface constructed wetlands: A review. Ecological Engineering, 61, 582-592

Walsh, S., 2012. A summary of climate averages for Ireland 1981-2010. Met éireann Climatological Note No. 14. http://www.met.ie/climate-ireland/SummaryClimAvgs.pdf. accessed September, 2017

Wu, S., Kuschk, P., Brix, H., Vymazal, J. and Dong, R., 2014. Development of constructed wetlands in performance intensification for wastewater treatment: A nitrogen and organic matter targeted review. Water Research 57, 40-55

Zhang, D., Jinadasa, K., Gersberg, R., Liu, Y., Ng, W and Tan, S., 2014. Application of constructed wetlands for treatment in developing countries- A review of recent developments. Journal of Environmental Management, 141, 116-131 